\title{
AFRIKA FOCUS wordt sinds 1988 uitgegeven door AFRIKA BRUG VZW
}

Afrika Brug vzw is lid van de Vereniging voor Wetenschappelijke en Culturele Tijdschriften

De artikels worden geabstraheerd in AGRIS (FAO)

Sekretariaat Afrika Brug: Seminarie Tropische Landbouw (RUG) Coupure Links 653

9000 Gent

tel.:091/64 6089

\section{Bestuur}

Prof. Dr. D. Beke, voorzitter

Dr. Ir. Patrick Van Damme, sekretaris

Dhr. Johan de Smedt, penningmeester

Prof. Dr. Patrick Wymeersch, bestuurder

\section{Leden van de algemene vergadering van de vereniging}

Afrika Vereniging van de Rijksuniversiteit Gent vzw. (AVRUG), vertegenwoordigd door Prof. Dr. M. Van Spaandonck (RUG)

Prof. Dr. Dirk Beke (RUCA/RUG)

Dr. Koen Bogers, Gent

Dhr. Gilbert Braspenning, Leiden

Dr. Else Bruyninx (RUG)

Dr. Morgan De Dapper (RUG)

Prof. Dr. André De Schaepdryver (RUG)

Dr. Antoon De Schryver (WGO, Genève)

Dhr. Johan De Smedt, Lokeren

Prof. Dr. René Devisch (KUL)

Prof. Dr. Ruddy Doom (RUG)

Prof. Dr. Henri Dumont (RUG)

Prof. Dr. Frans Pauwels (RUG)

Prof. Dr. Rik Pinxten (RUG)

Dhr. Guy Rayée, Gent

Prof. Dr. Filip Reyntjens (UIA/RUCA/KUL)

Prof. Dr. Hendrik Van Daele (RUG)

Prof. Dr. Fernand Vandamme (RUG)

Dr. Ir. Patrick Van Damme (RUG)

Prof. Dr. Patrick Wymeersch (RUCA) 


\section{Aanwijzingen voor auteurs}

a) De auteurs worden verzocht een kopij in drievoud te zenden, getypt met dubbele interlinie en brede marge, en bij voorkeur ook op een floppy disk of micro disk in Word Perfect*.

b) Elk artikel moet voorafgegaan worden door een korte samenvatting in het Engels en minimum drie Engelse trefwoorden.

c) Ook een korte identifikatie van de auteur moet bezorgd worden: naam, adres en specialisatie van het onderzoek.

d) De auteurs dienen in hun kopij duidelijk aanwijzingen te geven betreffende indelingen van hoofdstukken, paragrafen,... Citaten moeten eveneens duidelijk worden aangegeven.

e) Indien de auteur gebruik maakt van illustraties moet hij voor de reproduktie geschikt materiaal leveren. De illustraties zijn in zwart/wit; kleur kan op kosten van de auteur. Lijnillustraties moeten na eventuele verkleining leesbaar blijven tot op DIN A7. Alle formaten worden verkleind tot minimum DIN A7 (10 x 7) en maximum DIN A5 (21 x 15).

f) Noten moeten doorlopend genummerd worden in de tekst en achteraan bij de tekst toegevoegd worden.

g) Bibliografische aanduidingen, verwijzingen en citaten kunnen aangebracht worden zoals binnen de verschillende disciplines gebruikelijk is.

h) Iedere auteur ontvangt 3 nummers.

* BELANGRIJK: Om rechtstreekse overname mogelijk te maken worden de auteurs verzocht vooraf kontakt op te nemen met het sekretariaat.

\section{Instructions for authors}

a) Authors are requested to send three copies of their typewritten manuscript (double-spaced and with ample margins), and preferably also a floppy disk or a micro disk with the text in Word Perfect*.

b) The author is requested to provide a short summary in English and at least three English key words.

c) A short identification of the author is also to be provided: name, address and a short description of current research.

d) Authors should clearly indicate the divisions in chapters and paragraphs. Quotations should be clearly indicated.

e) If illustrations are used, the author must provide them in suitable form for reproduction. The illustrations will be printed in black and white; coulour is possible on the expense of the author. Graphs should be legible after reduction to DIN A7. All sizes will be reduced to a minimum of DIN A7 $(10 \times 7 \mathrm{~cm})$ or to a maximum of DIN A.5 $(21 \times 15 \mathrm{~cm})$.

f) Notes are indicated in the text by numbers in sequence and are listed separately.

g) Bibliographical indications, references and quotations can be marked as it is customary within the proper scientific discipline.

h) Authors will receive three copies.

* IMPORTANT: Please contact previously the secretariat for exact instructions about compatibility.

\section{Recommandations aux auteurs.}

a) L'auteur est prié d'envoyer son manuscrit en 3 exemplaires, dactylographiés de préférence (avec interligne double et grandes marges). Nous encourageons l'envoi de disquettes souples ou microdisquettes avec le texte en Word Perfect*.

b) Chaque texte doit être précédé d'un court résumé en anglais et d'au moins 3 mots-clés anglais.

c) Une brève note identifiant l'auteur est souhaitée: nom, adresse et domaine spécialisé d'études.

d) Les chapitres, paragraphes, alinéas etc. doivent être clairement indiqués, les citations explicitement signalees.

e) Les illustrations éventuelles doivent se prêter d la reproduction. Les illustrations sont en noir et blanc; couleur est possible sur les frais de l'auteur. Les graphiques doivent rester lisibles après réduction d DIN A7. Tous les formats seront réduits d DIN AS (réduction min. de $21 \times 15 \mathrm{~cm}$ ) et d DIN A7 (réduction max. de $10 \times 7 \mathrm{~cm}$ ).

f) Les notes et additions (numérotage continu) sont assemblées séparément a la fin du texte.

g) Les indications bibliographiques, les références et les citations seront indiquées conformément a l'usage dans les differentes disciplines scientifiques.

h) Chaque auteur recevra trois exemplaires d'Afrika Focus".

* IMPORTANT: Les auteurs peuvent s'adresser au secretariat pour toute information concernant la compatibilité des disquettes. 